\title{
A RARE CAUSE OF INTERNAL CAROTID ARTERY OCCLUSION: CATASTROPHIC ANTIPHOSPHOLIPID SYNDROME
}

\author{
Ahmet UBUR*, Erdal BODAKÇI**, Özlem AYKAÇ*, Zehra UYSAL KOCABAŞ*, Ezgi SEZER ERYILDIZ*, \\ Atilla Özcan ÖZDEMİ** \\ *Eskişehir Osmangazi University Faculty of Medicine, Department of Neurology, Eskişehir, TURKEY \\ **Eskişehir Osmangazi University Faculty of Medicine, Department of Rheumatology, Eskişehir, TURKEY
}

\begin{abstract}
Catastrophic antiphospholipid syndrome (CAPS) is a syndrome characterized by the presence of antiphospholipid antibodies and acute thrombosis of multiple organ systems. It causes small or large venous and arterial thrombotic occlusions and may be fatal if not aggressively treated. In this article, we aimed to present a case of possible CAPS with a deep thrombocytopenia and a cerebral infarction due to internal carotid occlusion and to emphasize that CAPS should be keep in mind in the differential diagnosis of young stroke patients.
\end{abstract}

Key Words: Ischemic stroke, internal carotid artery occlusion, catastrophic antiphospholipid syndrome.

\section{INTERNAL KAROTID ARTER OKLÜZYONUNUN NADİR BIR NEDENİ: KATASTROFIK ANTIFOSFOLIPID SENDROMU}

\section{ÖZET}

Katastrofik antifosfolipid sendromu (KAPS), antifosfolipid antikorları varlığında, akut gelişen ve birden fazla organ sisteminin trombozuyla karakterize antifosfolipid sendromunun ağır bir formudur. Küçük, büyük, venöz ve arteriyel trombotik oklüzyonlara sebep olmakta ve agresif tedavi edilmediğinde ölümcül olabilmektedir. Bu yazıda amacımız, derin trombositopeninin ve internal karotis arter oklüzyonuna bağlı serebral infarktın eșlik ettiği olası KAPS olgusunu sunarak genç iskemik inme hastalarında ayırıcı tanılar arasında akılda tutulması gerektiğini vurgulamaktır.

Anahtar Sözcükler: İskemik inme, internal karotis arter oklüzyonu, katastrofik antifosfolipid sendromu.

\section{INTRODUCTION}

Ischemic stroke is a significant health problem increasingly encountered in young adults. Its incidence is around 10 per 100.000 per annum in young adults (1). Cardioembolic stroke is the most common etiologic cause in young patients with ischemic stroke (1). Other causes defined among the risk factors are carotid artery dissection, hereditary thrombophilia, antiphospholipid syndrome, systemic lupus erythematosus and polycythemia (2).

Antiphospholipid syndrome (APS) is a systemic autoimmune disease characterized by thrombosis, pregnancy comorbidities and persistent antiphospholipid antibody positivity (3). Catastrophic antiphospholipid syndrome (CAPS) is a severe form of antiphospholipid syndrome characterized by acute onset and thrombosis of multiple organ systems in the presence of antiphospholipid antibodies (4). Although it occurs in $1 \%$ of patients with antiphospholipid syndrome, the mortality rate is $30-40 \%$ (5). Early diagnosis and subsequent aggressive treatment are the most important factors decreasing the mortality rate.

Corresponding author: Özlem Aykaç, MD. Eskişehir Osmangazi University Faculty of Medicine, Department of Neurology, Eskişehir, TURKEY

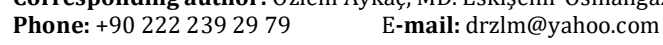

Received: $14.08 .2018 \quad$ Accepted: 12.11 .2018

This article should be cited as following: Ubur A, Bodakçı E, Aykaç Ö, Uysal Kocabas Z, Sezer Eryıldız E, Özdemir A. Ö. A rare cause of internal carotid artery occlusion: catastrophic antiphospholipid syndrome Turkish Journal of Cerebrovascular Diseases $2019 ; 25$ (2): 134-139. doi:10.5505/tbdhd.2018.62534 
Our aim in this study to present CAPS case accompanied by deep thrombocytopenia and cerebral infarcts associated with internal carotid artery thrombus, and to emphasize that it should be kept in mind among the differential diagnoses in young patients with stroke.

\section{CASE}

44-year-old female patient with high fever, nausea, vomiting, abdominal pain for 2 days, upon onset of weakness at left side and mental fog at 18:00, was brought to the emergency service by her relatives at 23:00. There was no feature in her history. She had no miscarriage and stillbirth history. She was neither a smoker nor an alcohol user. The body temperature of the patient was $37,2{ }^{\circ} \mathrm{C}$, and her blood pressure was $125 / 80$. Neurological examination revealed drowsiness, left central facial paralysis and hemiparesis in the left upper and lower extremities. The babinski was positive at the left side. Her white blood cell count was found as 9,5109/uL, hemoglobin as 13 $\mathrm{gr} / \mathrm{dl}$, thrombocyte as $18103 / \mathrm{uL}$, prothrombin time as 12 seconds, INR as 1.0, activated partial thromboplastin time as 33 seconds (24-40), fibrinogen as $424 \mathrm{mg} / \mathrm{dl}$ (200-400), D-dimer as 12 $\mathrm{ng} / \mathrm{mL} \quad(0-0,55)$, creatinin as $0,8 \mathrm{mg} / \mathrm{dl}$. No pathology was observed in computerized tomography scan of the head. Brain-neck CT angiography showed an occlusion of the right internal carotid artery and a consistent appearance with thrombus (Figure I).

No mismatch was observed in CT perfusion. The patient who was not indicated for endovascular treatment was admitted to the neuro intensive care unit. Cranial magnetic resonance imaging (MRI) and diffusion MRI showed diffusion restriction in the right basal ganglions (Figure II). The patient's ejection fraction was found as $65 \%$, and the wall movements and cardiac valves were found normal in the echocardiography performed in order to ostracise the cardioembolic etiology. Electrocardiography (ECG) showed normal sinus rhythm. Single platelets were found in the peripheral smear of the patient who was evaluated in terms of hematology for thrombocytopenia etiology, whereas no fragmented erythrocytes were observed, and no blast, atypical cell and hemolysis were detected. The ADAMTS-13 level was normal which was referred for Thrombotic Thrombocytopenic Purpura (TTP), Hemolytic
Uremic Syndrome (HUS) in which the thrombocytopenia and the thrombosis are seen together in differential diagnosis. The PNH panel checked in terms of paroxysmal nocturnal haemoglobinuria (PNH) was found negative. Although heparin-induced thrombocytopenia (HIT) was considered, there was no use of heparin. The Disseminated Intravascular Coagulopathy (DIC) was ostracized by peripheral smear findings. The patient was prescribed with fondaparinuks $2,5 \mathrm{mg} / \mathrm{sc}$ that has a low risk of bleeding. In the follow-up, the thrombocyte values reduced down to $6103 / \mathrm{uL}$. The thrombocyte replacement was performed. The thrombocyte levels remained below 10 103/uL for 5 days, despite replacement. The rheumatology department was consulted in terms of differential diagnoses of thrombosis and thrombocytopenia. The rheumatological system questioning was normal. The lupus anticoagulant was found positive at high titer in the tests required in terms of potential APS and Systemic Lupus Erythematosus (SLE). The possible CAPS was adopted because of hematologic system and cerebrovascular system involvement. Pulse methylprednisolone $1000 \mathrm{mg} /$ day therapy was applied for 3 days, and plasmapheresis was applied for 7 clinics, and upon regression of findings, the intravenous immunoglobulin (IVIG) treatment $0.4 \mathrm{~g} / \mathrm{kg}$ for 5 days was initiated. The thrombocyte level increased up to $40103 / \mathrm{uL}$ on the 4th day of the treatment. The serological tests planned by rheumatology, namely Anticardiolipin IgG and IgM, Anti Nuclear antibody (ANA) and anti-ds DNA were negative, whereas C3 and C4 were normal. However $\beta 2$ glycoprotein $1 \mathrm{~B} \operatorname{IgM}$ $189(0-40)$ and $\beta 2$ glycoprotein 1B IgG $100(0-40)$ were found to be high. The patient who was stable in terms of clinical and laboratory findings was initiated with hydroxychloroquine, warfarin treatment. She was referred to rehabilitation and then discharged. Her modified Rankin score in the 3 months was 1 .

\section{DISCUSSION}

Carotid artery occlusion is responsible for 26$30 \%$ of ischemic stroke cases (6). Internal carotid artery occlusion is known to have a high risk of cerebrovascular event. The mortality rate of occlusion in the acute period was reported to be $16-55 \%(7)$. 


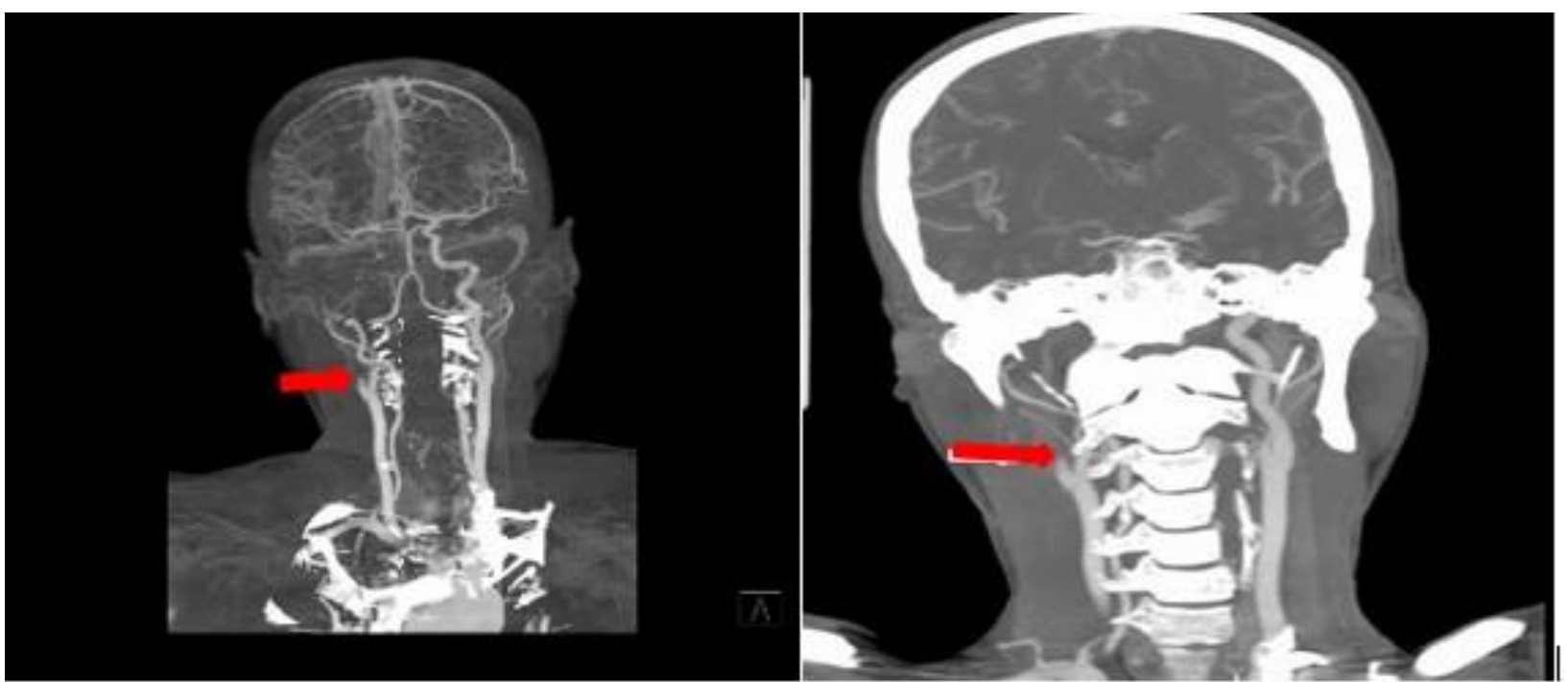

Figure I. The right internal carotid artery occlusion on brain-neck CT angiography.

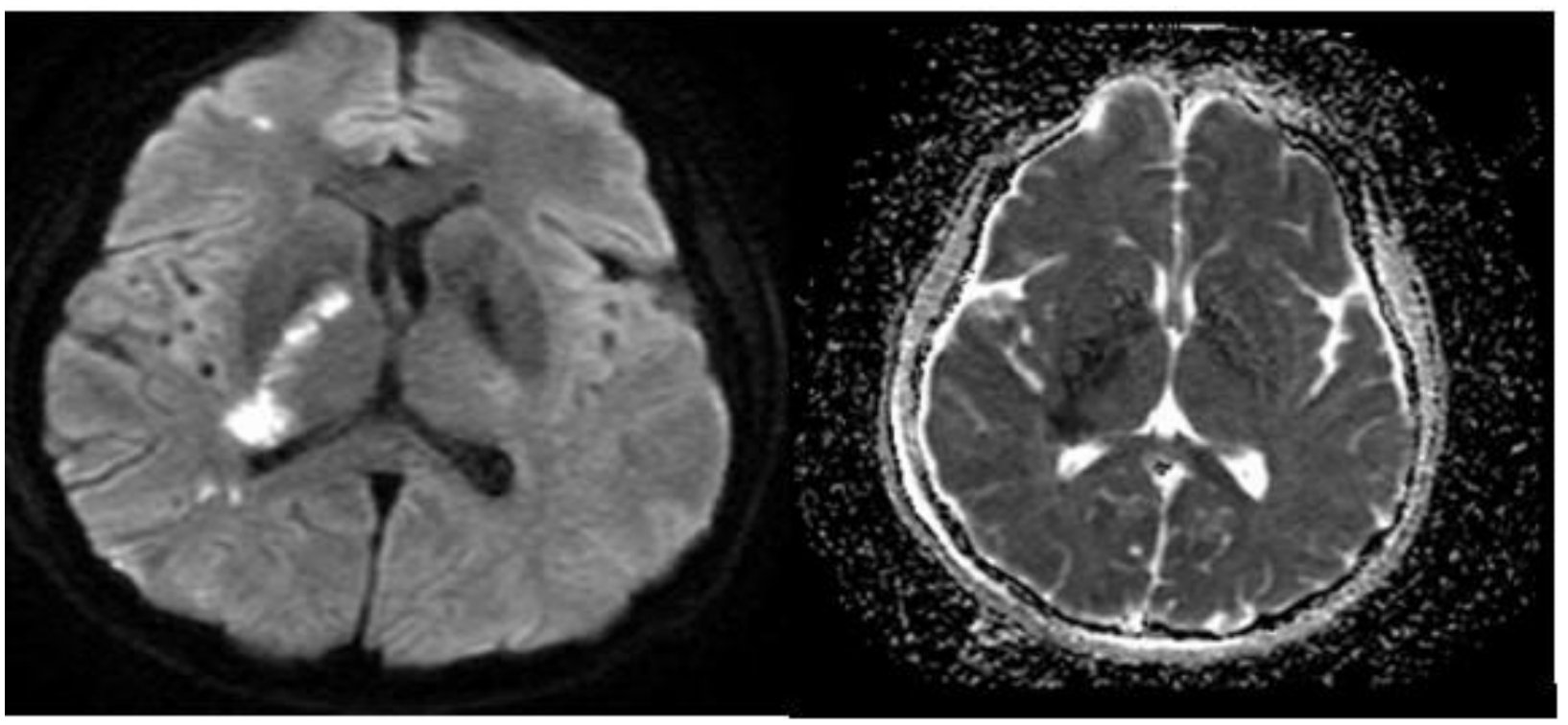

Figure II. The diffusion restriction in the right basal ganglions on diffusion MRI.

The most commonly used cause-specific system is TOAST classification. TOAST classification is an ischaemic stroke sub-type categorization system based on etiology and developed for Trial of Org 10172 in Acute Stroke Treatment (8). In accordance with this classification, the cerebrovascular diseases are classified depending on their etiologies in five groups as arterial atherosclerosis, cardioembolism, small vessel disease, stroke caused by another known cause, and stroke of unknown origin. According to the first ischaemic stroke etiology study in European young adults covering 15 provinces, the stroke group of unknown origin was found as the largest TOAST sub-group (39.6\%), while $21.6 \%$ of patients had other identified causes. $17.3 \%$ of the patients had cardioembolic etiologies (9). The most common high risk cardioembolic sources were atrial fibrillation, cardiomyopathy, intracardiac thrombus, mechanical heart valve replacement respectively (9). While carotid artery dissection in TOAST 4 subgroup was the most common cause with single etiology (12.8\%); other rare causes 
included in TOAST 4 subgroup may be listed as hereditary thrombophilia, anti-phospholipid antibody syndrome, non atherosclerotic vasculopathy, systemic lupus erythematosus, migraine infarcts, moyamoya disease, postradiation angiopathy, hematologic disorders, malignancies (9). APS is an auto-immune systemic disease emerging secondary to anti-phospholipid antibodies (aFL) with vascular thrombosis (artery, vein, small vessel) and/or pregnancy morbidity (A premature birth before the 34th gestational week due to unexplained fetal death after 10 weeks of pregnancy or preeclampsia, eclampsia, placental insufficiency or three unexplained pregnancy losses before 10 weeks of pregnancy) $(3,10) .13 \%$ of the patients who underwent ischemic stroke showed aFL positivity (11). When examined the neurological findings from 1000 patients diagnosed with APS in Euro-phospholipid project, it was found that $20,2 \%$ of such patients had migraine, $19,2 \%$ had stroke, $11,1 \%$ had transient ischemic attack, 7\% had epilepsia, 2,5\% had multiinfarct dementia, $1,3 \%$ had chore, and 1,1\% had acute encephalopathy (12). Today, lupusanticoagulant (LA), anticardiolipin (aCL), and anti$\beta 2$-glycoprotein-I (aß2GPI) ELISA tests are used for detection of aFL. In addition to clinical symptoms, a clinically significant aFL profile (at least 12 weeks apart, positive LA and/or medium/high titer aFL ELISA testing) is required for the diagnosis of APS (3). While the stroke and transient ischemic attack are the most common presentation of arterial thrombosis, the deep vein thrombosis (usually associated with pulmonary embolism) is the most common venous finding in APS. Rare region involvements such as mesenteric ischemia, adrenal infarction / insufficiency, BuddChiari syndrome and vascular occlusion of the eye can also be seen in APS patients. The clinical symptoms that might emerge depending on antiphospholipid antibodies (aFL) can be seen in five forms (13): 1 . Asymptomatic permanent aFL positivity, 2. APL symptoms not included in the Sapporo diagnostic criteria (livedo reticularis, thrombocytopenia, hemolytic anemia, aPLnephropathy, heart valve involvement), 3. Antiphospholipid syndrome (pregnancy morbidity only), 4. Antiphospholipid syndrome (vascular thrombosis) 5. Catastrophic antiphospholipid syndrome (CAPS).
Catastrophic antiphospholipid syndrome is accepted as a form of antiphospholipid syndrome which is a rare and has a high mortality (14).

Early diagnosis and aggressive treatment were shown to be important for the survival of the patient. Therefore, in patients with multiple organ failure, it is necessary to consider CAPS in differential diagnosis. The diagnosis criteria for CAPS were updated in 2010. While the retraction of the presence of another clinical condition to explain multiple organ thrombosis and/or micro thrombosis becomes important, the algorithms were developed for diagnosis (14) (Table I).

Table I. Pre-diagnostic criteria of catastrophic antiphospholipid syndrome.

1. Evidence of involvement of three or more organs, systems and / or tissues

2. Symptom development at the same time or in less than a week

3. Histopathological presentation of small vessel thrombosis in at least one organ or tissue**

4. Demonstrating the persistent presence of antiphospholipid antibodies (lupus anticoagulant and / or anticardiolipin antibodies)**

"Definitive" catastrophic APS

- - Simultaneous presence of 4 criteria

"Possible "catastrophic APS

- Criterion 2-3-4 and presence of only two organs, systems and / or tissue involvement

- Criteria 1-2-3 and the absence of aFL in patients at least 6 weeks apart >(eg. early death of the patient not tested for aFL before catastrophic APS)

- Criteria 1-2-4

- Criterion 1-3-4 and development of a third vascular event longer than one week but less than a month

**Vascular occlusion should have clinical evidence and, if possible, be demonstrated by imaging methods. **The presence of at least $50 \%$ increase in serum creatinine, severe systemic hypertension $(180 / 100$ $\mathrm{mmHg}$ ) and / or proteinuria ( $>500 \mathrm{mg} / 24 \mathrm{~h}$ ) is defined as renal involvement. ${ }^{* *}$ Thrombosis must be demonstrated by histopathological confirmation (with or without vasculitis). ${ }^{* *}$ If the patient has not previously been diagnosed with APS, it requires persistent demonstration of the presence of antiphospholipid antibody (two or more positive aFL tests at least 6 weeks apart).

Our patient was diagnosed with CAPS as the anticoagulant test was positive at high titer, $\beta 2$ glycoprotein 1B IgM and IgG were found high and they were still high in the control 6 weeks later, the symptoms developed in last 1 week, an appearance consistent with occlusion and thrombus in internal carotid artery was found in the imaging examinations although it could not be 
indicated buy biopsy, the presence of accompanying resistant thrombocytopenia and vascular system and hematologic system involvement. SLE and other connective tissue diseases were ostracized as serologically ANA, antds DNA negativity and complement tests were normal. The picture of multiple organ failure and infection that could cause thrombus in the patient were excluded clinically, microbiologically and by imaging. Other microangiopathic and thrombotic conditions such as TTP, DIC, HUS, HIT, PNH and sepsis were evaluated and excluded in the differential diagnosis of the patient. For this reason, the clinically prominent thrombotic and thrombocytopenic picture was thought to be associated with CAPS. Fondaparinux treatment that has low risk of bleeding was initiated due to treatment-resistant thrombocytopenia and ICA thrombosis. Similar to our patient, a 48-year-old female patient applied with a left internal carotid artery thrombosis, her anticardiolpin IgG tests were found positive in medium titer and the patient was diagnosed as APS (15).

There are three main objectives in CAPS treatment (5): Treatment of precipitating factor (i.e: infection), prevention and treatment of thrombotic events, suppression of cytokin secretion and cleaning of cytokines. For this purpose, anticoagulant therapy, corticosteroid, plasmapheresis and intravenous immunoglobulin are recommended.

Infection, surgical interventions, discontinuation of anticoagulant therapy and use of oral contraceptives may trigger CAPS. In our case, complaints developed following acute gastroenteritis attack. It was observed in our intensive care unit that gastroenteritis symptoms regressed spontaneously.

Following the diagnosis, our patient was initiated on anticoagulant treatment, pulse and oral steroid treatment thereafter, plasma exchange and IVIG combination. On the 4th day of this treatment, the number of thrombocytes reached up to $40103 / \mathrm{uL}$ and in the following days continued beyond $150103 / \mathrm{uL}$. The patient regained consciousness, the orientation and cooperation were established. In accompaniment with rehabilitation, the patient was initiated on hydroxychloroquine $200 \mathrm{mg} /$ day and warfarin treatment so as to allow INR reading maintain between 2-3.
In conclusion, APS and CAPS that has a high mortality should be considered primarily in young patients with ischemic stroke and known collagen tissue disease and especially lupus, who have an abortus history, and thrombosis accompanied by thrombocytopenia that have no risk factors. After diagnosis of CAPS, the anticoagulant treatment should not be delayed despite thrombocytopenia. Rapid and aggressive treatments can provide promising results.

\section{REFERENCES}

1. Simonetti BG, Mono M-L, Huynh-Do U, Michel P, Odier C, Sztajzel R, et al. Risk factors, aetiology and outcome of ischaemic stroke in young adults: the Swiss Young Stroke Study (SYSS). Journal of neurology. 2015; 262(9): 20252032.

2. Varona J, Guerra J, Bermejo F, Molina J, De La Cámara AG. Causes of ischemic stroke in young adults, and evolution of the etiological diagnosis over the long term. European neurology. 2007; 57(4): 212-218.

3. Miyakis S, Lockshin MD, Atsumi T, Branch DW, Brey RL, Cervera $\mathrm{R}$, et al. International consensus statement on an update of the classification criteria for definite antiphospholipid syndrome (APS). Journal of Thrombosis and Haemostasis. 2006; 4(2): 295-306.

4. Asherson R, Cervera R, De Groot P, Erkan D, Boffa M, Piette $\mathrm{J}$, et al. Catastrophic antiphospholipid syndrome: international consensus statement on classification criteria and treatment guidelines. Lupus. 2003; 12(7): 530-534.

5. Asherson RA, Pierangeli S, Cervera R. Microangiopathic antiphospholipid-associated syndromes revisited new concepts relating to antiphospholipid antibodies and syndromes. The Journal of rheumatology. 2007; 34(9): 1793-1795.

6. Michel P, Odier C, Rutgers M, Reichhart M, Maeder P, Meuli $\mathrm{R}$, et al. The Acute STroke Registry and Analysis of Lausanne (ASTRAL): design and baseline analysis of an ischemic stroke registry including acute multimodal imaging. Stroke. 2010; 41(11): 2491-2498.

7. Klonaris C, Alexandrou A, Katsargyris A, Liasis N, Bastounis E. Late spontaneous recanalization of acute internal carotid artery occlusion. Journal of vascular surgery. 2006; 43(4): 844-847.

8. Chen PH, Gao S, Wang YJ, Xu AD, Li YS, Wang D. Classifying ischemic stroke, from TOAST to CISS. CNS neuroscience \& therapeutics. 2012; 18(6): 452-456.

9. Yesilot Barlas N, Putaala J, Waje-Andreassen U, Vassilopoulou S, Nardi K, Odier C, et al. Etiology of firstever ischaemic stroke in European young adults: the 15 cities young stroke study. European Journal of Neurology. 2013; 20(11): 1431-1439.

10. Anand P, Mann SK, Fischbein NJ, Lansberg MG. Bilateral internal carotid artery occlusion associated with the antiphospholipid antibody syndrome. Case Rep Neurol. 2014; 6(1): 50-54.

11. Andreoli L, Chighizola CB, Banzato A, Pons-Estel GJ, de Jesus GR, Erkan D, et al. Estimated frequency of antiphospholipid antibodies in patients with pregnancy morbidity, stroke, myocardial infarction, and deep vein

Turkish Journal of Cerebrovascular Diseases 2019; 25 (2): 134-139 Ubur et al. 
thrombosis: a critical review of the literature. Arthritis care \& research. $2013 ; 65(11): 1869-1873$.

12. Cervera R, Piette JC, Font J, Khamashta MA, Shoenfeld Y, Camps MT, et al. Antiphospholipid syndrome: clinical and immunologic manifestations and patterns of disease expression in a cohort of 1,000 patients. Arthritis \& Rheumatism: Official Journal of the American College of Rheumatology. 2002 ;46(4): 1019-1027.
13. Deligöz Bildacı Y, Erkan D. Katastrofik antifosfolipid sendromu: Tanısal zorluklar ve güncellenmiş tanı algoritmaları. RAED Dergisi. 2012; 3(Online Preprint Issue).

14. Erkan D, Espinosa G, Cervera R. Catastrophic antiphospholipid syndrome: updated diagnostic algorithms. Autoimmunity reviews. 2010; 10(2): 74-79.

15. Marques MA, Murad FF, Ristow AV, Silveira PR, Pinto JE, et al. Acute carotid occlusion and stroke due to antiphospholipid antibody syndrome: case report and literature review. Int Angiol. 2010; 29(4): 380-384. 